\title{
Laboratory Studies on the Evolution of lodine-129 \\ During Purex-Uranium Metal Dissolution
}

\author{
L. A. Bray
}

March 1980

Prepared for the U.S. Department of Energy under Contract DE-AC06-76RLO 1830

Pacific Northwest Laboratory Operated for the U.S. Department of Energy by Battelle Memorial Institute 
NOTICE

This report was prepared as an account of work sponsored by the United States Government. Neither the United States nor the Department of Energy, nor any of their employees, nor any of their contractors, subcontractors, or their employees, makes any warranty, express or implied, or assumes any legal liability or responsibility for the accuracy, completeness or usefulness of any information, apparatus, product or process disclosed, or represents that its use would not infringe privately owned rights.

The views, opinions and conclusions contained in this report are those of the contractor and do not necessarily represent those of the United States Government or the United States Department of Energy.

PACIFIC NORTHWEST LABORATORY

operated by

BATTELLE

for the

UNITED STATES DEPARTMENT OF ENERGY

Under Contract DE-AC06-76RLO 1830

\author{
Printed in the United States of America \\ Available from \\ National Technical Information Service \\ United States Department of Commerce \\ 5285 Port Royal Road \\ Springfield, Virginia 22151
}

Price: Printed Copy 5

$\therefore$ Microfiche $\$ 3,00$

NTIS

- Pages Selling Price

$\begin{array}{ll}001-025 & \$ 4.00 \\ 026-050 & \$ 4.50 \\ 051-075 & \$ 5.25 \\ 076-100 & \$ 6.00 \\ 101-125 & \$ 6.50 \\ 126-150 & \$ 7.25 \\ 151-175 & \$ 8.00 \\ 176-200 & \$ 9.00 \\ 201-225 & \$ 9.25 \\ 226-250 & \$ 9.50 \\ 251-275 & \$ 10.75 \\ 276-300 & \$ 11.00\end{array}$




\title{
33679000552200
}

\author{
LABORATORY STUDIES ON THE \\ EVOLUTION OF IODINE-129 \\ DURING PUREX-URANIUM METAL \\ DISSOLUTION
}

L. A. Bray

March 1980

Prepared for

the U.S. Department of Energy

under Contract DE-ACO6-76RLO 1830

Pacific Northwest Laboratory

Richland, Washington 99352 
$\checkmark$ 


\section{SUMMARY}

The path of iodine from the Purex dissolver was determined during fuel dissolution using ${ }^{125}$ I tracer. Laboratory-scale equipment qualification studies were completed using sections of nonirradiated uranium $N$-reactor fuel elements. A proof-of-principle dissolution study was completed at the end of FY 79 in the PNL hot cells using wafers of irradiated N-reactor fuel. The findings from these studies include the following:

- The laboratory-scale dissolver/downdraft condenser was designed at a factor of $5 \times 10^{-5}$ of the Purex flowsheet.

- With no refluxing, 5.6 moles of $\mathrm{HNO}_{3}$ were required per mole of dissolved uranium. With $\mathrm{NO}_{x}$ recovery in the reflux stream, an average of 3.6 moles of $\mathrm{HNO}_{3}$ was required. These results formed the basis for adequate modeling of the laboratory Purex downdraft dissolver.

- Approximately $8 \%$ of the iodine was found in the final dissolver solution when the ${ }^{125}$ I tracer was added to the initial dissolver solution prior to the first cut, 6-hr dissolution.

- When the ${ }^{125}$ I was added continuously during the 6-hr dissolution without any refluxing of the condenser acid back to the dissolver, approximately $16 \%$ of the iodine was found in the dissolver solution.

- When irradiated $\mathrm{N}$-reactor fuel was dissolved while ${ }^{125}$ I tracer was continuously added to the dissolver during the $6-h r$ test, $11 \%$ of the ${ }^{125}$ I tracer was found in the dissolver solution. After $2 \mathrm{hr}$ of refluxing with air sparging, $6 \%$ of the ${ }^{125}$ I tracer was found in the dissolver solution.

- Analysis of the fission product ${ }^{129} \mathrm{I}$ in the fuel duplicated the tracer study results with $8 \%$ and $7 \%$ of the iodine remaining in the dissolver solution after 6 and $8 \mathrm{hr}$, respectively. 
?

$\vdash$ 


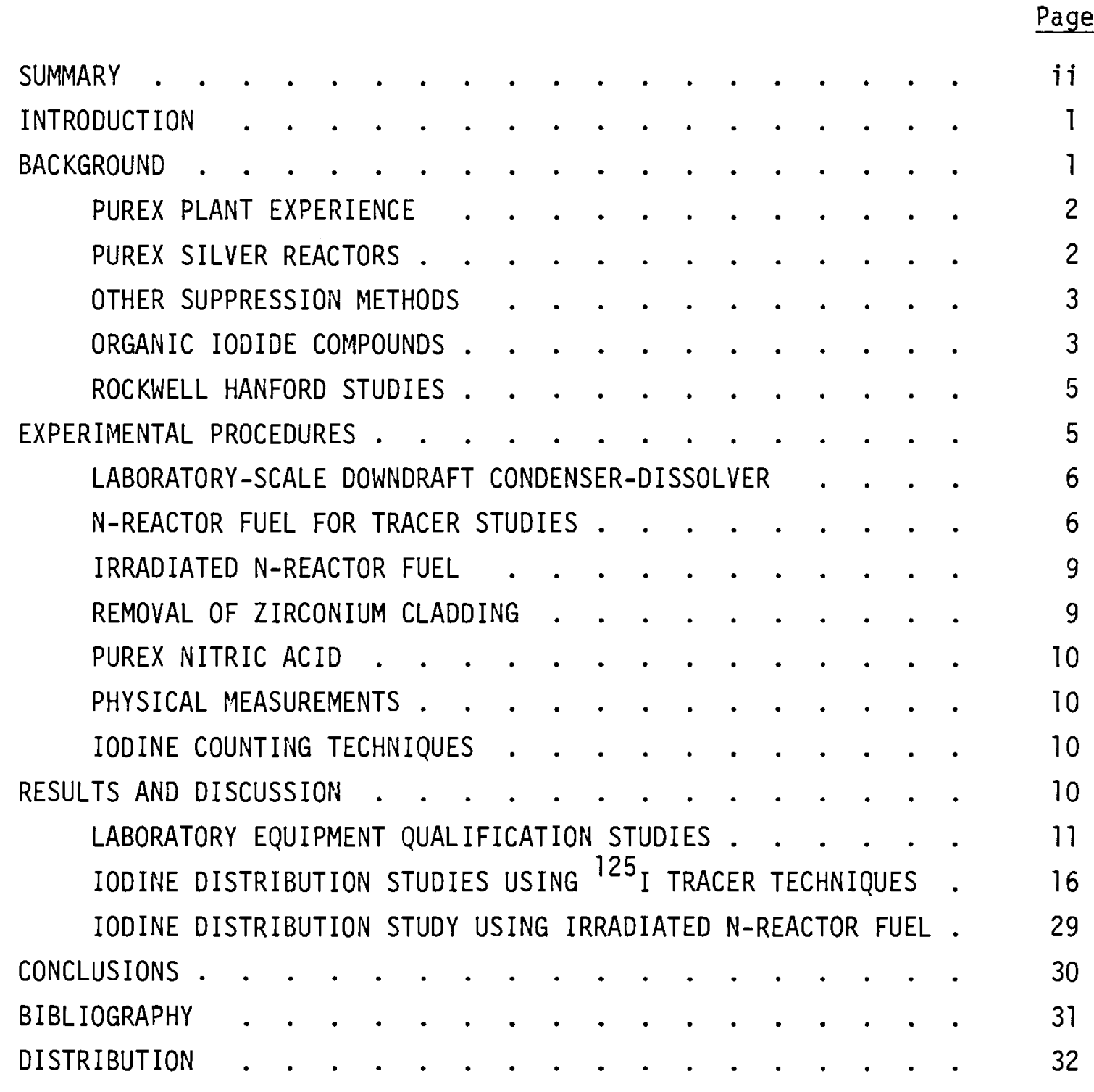


.

. 


\section{$\underline{\text { TABLES }}$}

No.

Page

1 Test Conditions and Summary of Results for the Tracer Studies and the Hot Cell Study

2 Summary of Uranium Metal Dissolution - - Test 3 . . . . . . 18

3 Loss of Iodine from a Dissolver Solution with Refluxing and

Air Sparging as a Function of Time $\quad$. . . . . . . . 18

4 Summary of Uranium Metal Dissolution -- Test 5 . . . . . . 21

5 Summary of Uranium Metal Dissolution -- Test 6 . . . . . . . 23

6 Physical Measurements of $0.95 \%$ Enriched Inner N-Reactor Fuel -Before and After Dissolution Test $6 \quad$. . . . . . . 24

7 Summary of Uranium Metal Dissolution -- Test 7 . . . . . . 26

8 Summary of Uranium Metal Dissolution -- Test 8 . . . . . . . 28

9 The Results of the Iodine Analyses for the N-Reactor Fuel

Dissolution Test . . . . . . . . . . . . . . . . 30

\section{FIGURES}

1 Laboratory-Scale Purex Downdraft Condenser/Dissolver . . . 7

2 Unirradiated $\mathrm{N}$-Reactor Fuel Element Test Segments . . . . 8

3 Iodine Observed in Downdraft Condenser -- Test 2 . . . . . 14 


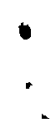




\section{INTRODUCTION}

This report presents the results of laboratory studies performed for Rockwell Hanford Operations by the Pacific Northwest Laboratory (PNL), which is operated by Battelle Memorial Institute for the Department of Energy (DOE). The PNL studies concerned the control of ${ }^{129}$ I during the reprocessing of $\mathrm{N}$-reactor fuel.

The objective of this research was to determine the path of iodine from the Purex dissolver during fuel dissolution. Laboratory qualification studies using sections of metal fuel elements and an iodine tracer were done to determine the behavior of iodine. These were followed during FY 1979 by a proof-ofprinciple dissolution study in the hot cell using wafers of $\mathrm{N}$-reactor fuel.

\section{BACKGROUND}

A program for the control of ${ }^{129}$ I during zirconium-clad fuel reprocessing at Purex has been outlined by D. W. Jeppson in a letter to H. A. Babad on September 30, 1975. Jeppson stated that laboratory data are needed on the rate of iodine evolution during a typical zirconium-clad coating removal and acid dissolution of uranium. If greater than $1 \%$ of the iodine remains in the dissolver after acid dissolution, then methods may be required enhancing evolution. In previous operating periods at the Purex plant, very little data were obtained on ${ }^{129}$ I releases via the off-gases and condensate. In future operations of the plant, a decontamination factor (DF) of about 1000 is needed in the dissolver off-gas stream (assuming that most of the iodine leaves in the dissolver off-gas) to ensure that the DOE stack release 1 imit of $0.02 \mathrm{pCi} / \mathrm{L}$ of released air for ${ }^{129} \mathrm{I}$ is not exceeded. A DF of 4600 is required to comply with the DOE release limit of $60 \mathrm{pC} i / L$ for the process condensate (Jeppson 1976). (a)

During future fuel reprocessing operations at Purex, routes of ${ }^{129}$ I from the plant are expected to be the silver reaction collection inventory, coating waste, off-gases, organic wash wastes, process condensate, uranium nitrate products, and high-level wastes. It is desirable to force most of the iodine out of the dissolver solution into the dissolver off-gas stream for collection in an efficient iodine removal system.

(a) Jeppson used an instantaneous limit for determining DF's (total ${ }^{129}$ I in the feed divided by the total iodine release). Based on an operating period the DF would be $\sim 330$, and on a yearly basis the required DF would be $₫ 0$ for Table II requirements. 


\section{PUREX PLANT EXPERIENCE}

C. H. Holm (1951a) found that nitric acid dissolution of Hanford uranium with the sparging action of the gases carried $280 \%$ of the iodine out of the solution. Sparging and carrier precipitation have been investigated for removal of iodine from dissolver solution. About $50 \%$ of the iodine was released by sparging.

Holm (1951b) studied the removal of iodine as iodide, iodine, and iodate. He showed that iodine removal increased with increasing temperature. Oxygen, air, and nitrogen affected the iodine removal only slightly, but the flow rate of the gas markedly increased the iodine removal. The presence of uranium metal in the solution caused a more rapid removal of iodine and iodate but a slower removal of iodide. Nitric acid concentration had a definite effect on the rate of iodine evolution for all the oxidation states studied. The uranyl nitrate concentration did not affect iodine removal between $1.5 \underline{M}$ and $2.2 \underline{M}$ uranium. At a sparging flow rate of $0.4 \mathrm{~cm}^{3} / \mathrm{min} / \mathrm{ml}$, removal of $65 \%, 73 \%$, and $65 \%$ of the iodine added as iodide, iodine, and iodate, respectively, was achieved after $3 \mathrm{hr}$.

Many different iodine evolution values have been reported during uranium dissolution at various reprocessing facilities. Aluminum-clad fuel at the Hanford Purex Plant resulted in $95 \%$ of the iodine being evolved during air sparging and recycling of the dissolver condensate. The path of iodine from the Hanford Purex dissolver during zirconium-clad fuel reprocessing has not been determined (Schmidt 1957).

\section{PUREX SILVER REACTORS}

Early experience at the Savannah River Plant showed that approximately $50 \%$ of the iodine is volatilized during dissolution. In normal processing of two batches of uranium, the iodine DF for the silver nitrate reactors was 10 and 6 . A DF of 530 was measured during a special neptunium processing campaign. Of the $1600 \mathrm{Ci}$ of ${ }^{131}$ I charged, 3 Ci vere released during all processing steps. The high retention factor was attributed to $0.005 \mathrm{M}$ mercuric ion present during dissolution (Sheldon 1977). 
Iodine at the Hanford Purex Plant is controlled by passing the off-gas from the fuel dissolvers through a bed of unglazed ceramic saddles coated with silver nitrate. Early operating reports indicate that the dissolver silver reactors were removing $99 \%$ to $99.9 \%$ of the ${ }^{131}$ I. Reports from 1968 indicate a $90 \%$ to $95 \% 131$ I removal. Schmidt (1957) reported that "Additional data will be required to determine if silver nitrate reactors can effectively be used to remove iodine during future Purex operations or if studies of alternatives are warranted."

OTHER SUPPRESSION METHODS

Other methods for the suppression of iodine have been suggested: (1) the use of mercury $(\mathrm{Hg}),(2)$ the use of $\mathrm{MnO}_{2}$ and gelatin to release iodine from the dissolver solution to the atmosphere, and (3) precipitation of iodine from dissolution solutions using paladium for long-term storage.

Smith (1968) at Savannah River has described a series of tests conducted to determine the suppression effect of various mercury concentrations on ${ }^{131}$ I evolution during Purex operation. Without mercury, $50 \%$ of the iodine is evolved. When $0.04 \mathrm{M} \mathrm{Hg}^{2+}$ was added to the dissolver, approximately $1 \%$ of the iodine was released during dissolution. Some iodine remained in the organic tributyl phosphate (TBP) extractant where it was slowly released by caustic scrubbing. The uranyl nitrate dissolver solution is then transferred to a clarification tank and a solution of $1 \%$ gelatin is added before centrifugation; most of the iodine is released during gelatin precipitation. For special materials, $\mathrm{MnO}_{2}$ instead of gelatin is used; $\mathrm{MnO}_{2}$ is generated by first adding manganous nitrate and then slowly adding potassium permanganate. In this way most of the iodine is released to the atmosphere. During solvent extraction, the remaining iodine extracts with the solvent and remains until removed by caustic scrubbing.

Mailen and Horner (1977) have suggested that jodine be removed from the dissolver solution by the addition of hydroxylamine $\left(\mathrm{NH}_{2} \mathrm{OH} \cdot \mathrm{HNO}_{3}\right)$ to cause precipitation of insoluble $\mathrm{PdI}_{2}$, which is suitable for long-term storage.

QRGANIC IODINE COMPOUNDS

Several researchers have observed organic radioiodine compounds in the off-gas from a nuclear fuel separations plant. 
Perkins' (Haller and Perkins 1967) studies of the gaseous stack effluents from the Hanford nuclear fuel separations plant indicated that a large fraction of the ${ }^{131} I$ was in organic forms. The ratio of the organic to inorganic radioiodine released in the Purex plant's gaseous effluent was determined after Perkins compared samples of the radioiodine which was concentrated by bubbling the gas directly into a liquid nitrogen-cooled trap. During a 20-day period the ratio of organic to inorganic radioiodine varied from 0.12 to 1.47 .

E. Tachikawa and others (Numakura, Saeki, and Tachikawa 1973) found that organic iodides were formed by the reaction of carrier-free ${ }^{131}$ I in nitric acid solutions, and that their yield was dependent on the concentration of nitric acid. In the actual reprocessing of the irradiated fuel on a large scale, $10 \mathrm{M} \mathrm{HNO}_{3}$ is used. The amount of organic jodide was found to be in the range of $1 \%$ to $4 \%$ of the total iodine found at dissolving temperatures which are from $90^{\circ}$ to $115^{\circ} \mathrm{C}$. It markedly diminished as the dissolving temperature was decreased, and it was only $0.2 \%$ at $70^{\circ} \mathrm{C}$. The addition of various iodine compounds into the concentrated nitric acid also changed the amount of iodine and the percent of organic iodine found in the sodium hydroxide trap. There was also a noticeable effect when other acids were used. When concentrated $\mathrm{HCl}$ rather than $\mathrm{HNO}_{3}$ was used as a dissolving agent, methyl iodide amounted to less than 0.1\% (Tachikawa 1971). From this paper, no suggestion was made concerning the source of the carbon for the formation mechanisms of the organic iodides.

Eggleton and Atkins (1964) identified methyl iodide as the principal iodine compound formed when amounts of carrier-free ${ }^{131}$ I were released in the gas phase by the oxidation of $\mathrm{Na}^{131} \mathrm{I}$ and neutron-irradiated uranium metal or by the heating of irradiated $\mathrm{UO}_{2}$ in mixtures containing $\mathrm{CO}_{2}$.

Tachikawa (Saeki, Numakura, and Tachikawa 1974) and others further examined $\mathrm{CO}_{2}$ and discounted it as a source of carbon. The results obtained with various carbon compounds indicated that an important carbon source is high-molecularweight organic compounds which are mostly contained in $\mathrm{HNO}_{3}$ as an impurity. Furthermore, the information contained by the purification of $\mathrm{HNO}_{3}$ and by replacing the flushing gas, He, by $\mathrm{O}_{2}$ revealed that the organic iodides are formed by radical reactions of the organic species that result from fragmentation of organic compounds with ${ }^{131} \mathrm{I}$. 
ROCKWELL HANFORD STUDIES

D. M. Strachan, in letters to D. C. Lini in March and April of 1976 and in June of 1977 , reported that he completed tracer-ievel experiments to determine the pathways of radioiodine in the Purex operations. Problems were encountered during the investigation due to the small quantities of iodine and the large sampling volumes. Solutions were spiked with ${ }^{131}$ I before and after dissolution of Zircaloy cladding and again after uranium dissolution. It was determined that:

- At the Zircaloy-uranium interface, $40 \%$ to $50 \%$ of the iodine present vaporized.

- During uranium dissolution, $90 \%$ to $95 \%$ of the remaining iodine volatilized.

- Organic iodides volatilized in proportion to the boiling point with methyl iodide $\left(\mathrm{CH}_{3} \mathrm{I}\right)$ completely volatilized.

Poor iodine material balance was observed during dissolution of a wafer of $\mathrm{N}$-reactor fuel. Most of the tracer work has been completed in the project to identify the pathways of ${ }^{129} \mathrm{I}$ in Purex. Tracer work shows that 1 ess than $90 \%$ of the iodine is volatilized during dissolution of uranium metal.

\section{EXPERIMENTAL PROCEDURES}

The path of jodine from the laboratory scale Purex dissolver was determined during fuel dissolution. The amount of iodine was measured in the off-gas and nitric acid feed. Laboratory qualification studies using sections of unirradiated fuel elements and ${ }^{125}$ I tracer were done to determine the behavior of iodine during uranium dissolution. The initial results formed the basis for additional laboratory-scale studies and a proof-of-principle dissolution study using irradiated $\mathrm{N}$-reactor fuel. The laboratory-scale program provides a technical basis for determining the adequacy of the iodine control system during future Purex plant operation.

During the initial program review, the following major points were outlined: 
- The laboratory chemical flows will be based on a factor of $2 \times 10^{4}$ of the Purex flowsheet (Jeppson 1976).

- The design of the laboratory-scale downdraft condenser based on the acid required for uranium dissolution will be accepted as adequate modeling. With no reflux, approximately 5.5 moles of $\mathrm{HNO}_{3}$ are required per mole of uranium. However, with $\mathrm{NO}_{2}$ recovery in the reflux stream, plantexperience shows that 3 to 4 moles of $\mathrm{HNO}_{3}$ per mole of uranium are required.

- Initial laboratory and hot-cell studies will focus on the nitric acid dissolution of uranium.

- Since all acid used in dissolution is recycled $\mathrm{HNO}_{3}$, the potential exists for organics, such as TBP or its degradation products, to be present in the recycled acid in significant quantities. This is expected to have a pronounced effect on both the amount and species of iodine that evolve. The effect of recycled acid will not be included in the initial tracer study.

\section{LABORATORY-SCALE DOWNDRAFT CONDENSER-DISSOLVER}

A laboratory-scale downdraft condenser fabricated for previous Purex studies and a dissolver were modified for the initial investigation. Figure 1 illustrates this equipment which includes the off-gas sampling traps and support equipment.

\section{N-REACTOR FUEL FOR TRACER STUDIES}

Approximately $2000 \mathrm{~g}$ of uranium metal (unannealed) was initially obtained for this study. Before the dissolution was started, the zirconium-clad half-circles of metal were conditioned by contact with hot $\mathrm{HNO}_{3}$ for 15 to $30 \mathrm{~min}$. The acid leachant removed the uranium oxide film and the organic oils present from handling and cutting the half-circles. Figure 2 shows the uranium metal (including the the zirconium cladding freed from the uranium metal) before and after dissolution. After completion of test 3 , it was noted that the dissolver penetration was greater on the cut ends of the fuel than on the curved surfaces. Since dissolution rates may vary with the physical properties of the metal, annealed metal was obtained for the remaining tests. 


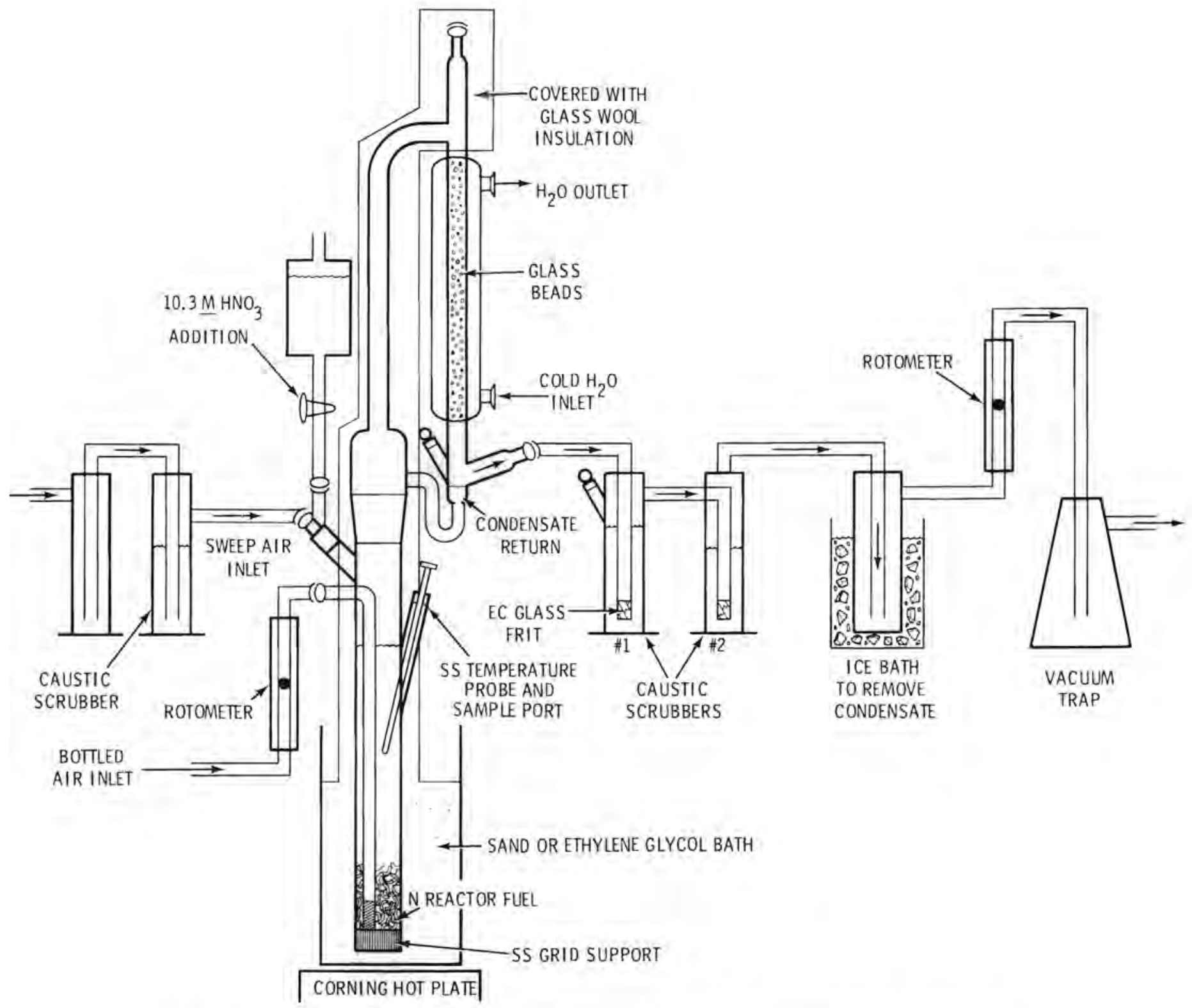

FIGURE 1: Laboratory-Scale Purex Downdraft Condenser/Dissolver 


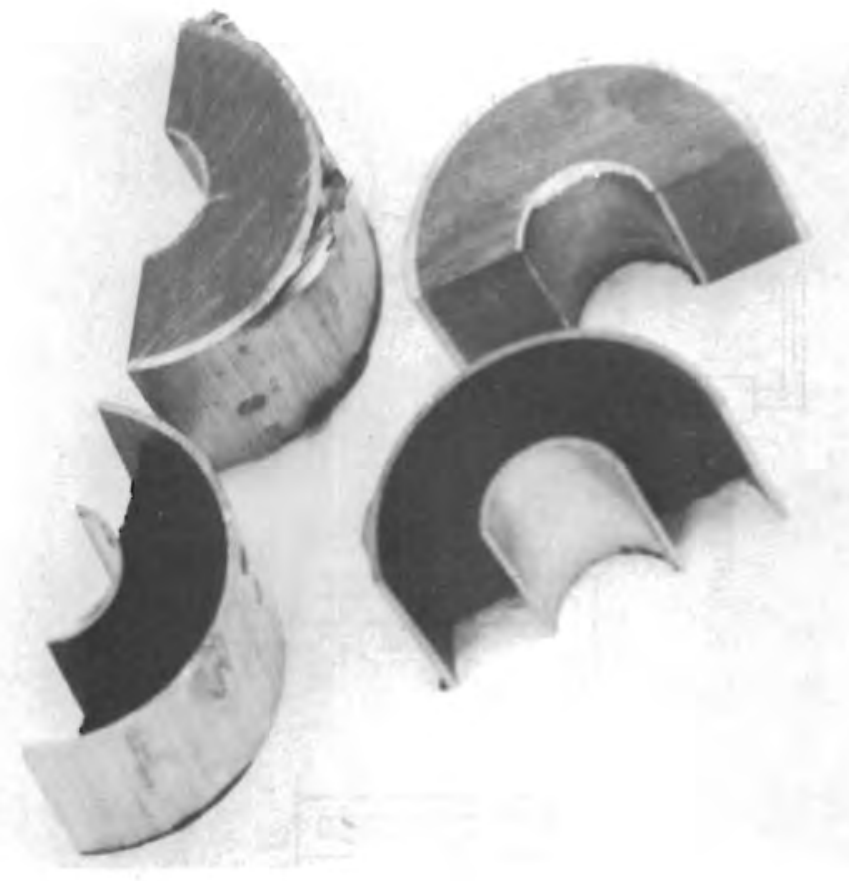

Before Dissolution

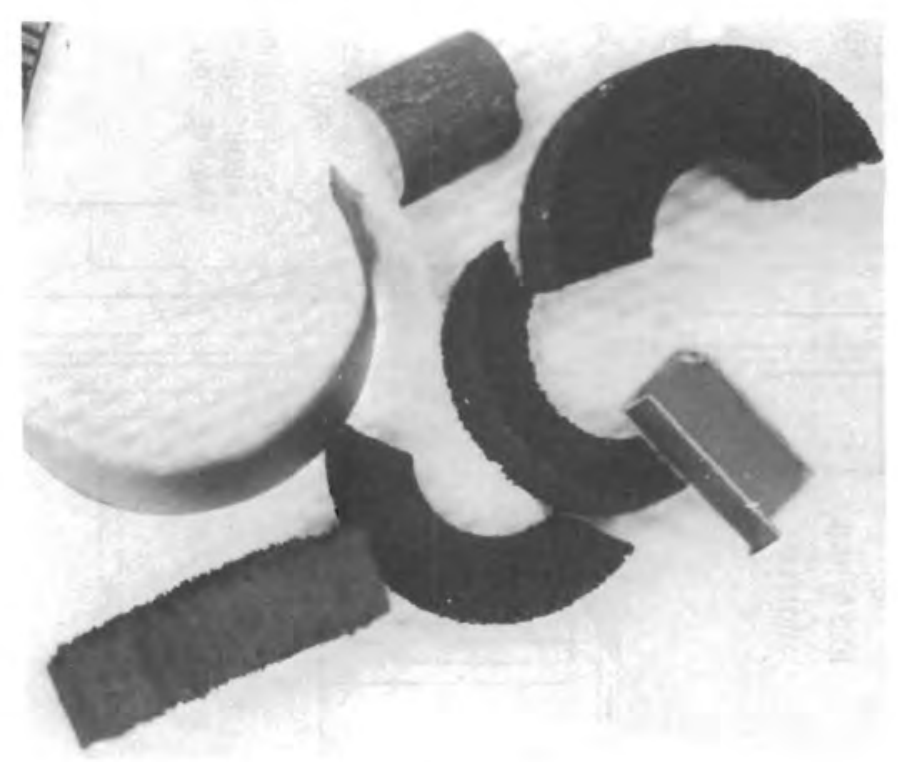

After Partial Dissolution

FIGURE 2: Unirradiated N-Reactor Fuel Element Test Segments 
Heat-treated uranium metal for tests 5 through 8 was prepared by Glenn Burnett of UNC Nuclear Industries, Inc., Hanford. Twenty half-circles of zirconium-clad, heat-treated uranium were cut from an inner xog fuel element with an enrichment of $0.947 \%{ }^{235} \mathrm{U}$.

IRRADIATED N-REACTOR FUEL

An inner (1.45 in. OD), irradiated $N$-reactor fuel pin was obtained through the cooperation of J. P. Schmidt, manager of Fuel Engineering at UNC Nuclear Industries, Inc. The Post Irradiation Testing Facility at the Hanford Engineering Development Laboratory sectioned the fuel element, and twenty 1/2-inch semi-circles were sent to the PNL 325-A hot cells for testing. The history of the fuel pin is given below:

- in reactor --- 13 July 1977

- out of reactor --- 15 May 1978

- 6th fuel pin from the downstream end

- $2000 \mathrm{MWd} /$ tonne burnup

- $0.947 \% 235_{\mathrm{U}}$

- 1.45 in. 00

REMOVAL OF ZIRCONIUM CLADDING

The zirconium cladding was dissolved off the uranium metal fuel surface by use of the Zirflex method. Approximately $500 \mathrm{~g}$ of fuel were placed in a $1.2 \mathrm{~L}$ Teflon lined stainless steel beaker with $500 \mathrm{ml}$ of solution containing $5.6 \mathrm{M} \mathrm{NH} 4 \mathrm{~F}$ and $0.5 \mathrm{M} \mathrm{NH}_{4} \mathrm{NO}_{3}$. The solution was heated for $6 \mathrm{hr}$ at 80 to $90^{\circ} \mathrm{C}$. Water was added to maintain the volume. The off-gas was scrubbed through a $0.5 \mathrm{M} \mathrm{NaOH}$ bubbler trap connected to a large funnel. The funnel acted as a cover for the heated beaker, and the fumes were contained in the caustic trap. After completion of zirconium dissolution, the uranium metal was washed with $\mathrm{HNO}_{3}$ and $\mathrm{H}_{2} \mathrm{O}$. 


\section{PUREX NITRIC ACID}

Recycled acid from the Purex plantwas sampled to determine the carbon content. The sample was taken from a process tank containing acid estimated to be five to six years old and recently (1979) diluted with process water. The original concentration of nitric acid should have been approximately $10 \mathrm{M} \mathrm{HNO}_{3}$. The analys is by the 222-S Laboratory at Rockwell Hanford Operations of the acid sent for this study was as follows:

- $5.34 \underline{M}$ in $H^{+}$

- 5.34 M in $\mathrm{NO}_{3}^{-}$

- $<1.5 \times 10^{-4} \underline{\mathrm{M}}$ in oxides as $\mathrm{NO}_{2}^{-}$

- $0.055 \mathrm{~g} / \mathrm{L}$ in total organic carbon

- $<1.68 \mathrm{pCi} / \mathrm{ml}$ in ${ }^{129} \mathrm{I}$

When received, it was determined that the bright yellow color in the acid was due to the sample containing $5.4 \mathrm{~g} \mathrm{U} / \mathrm{L}$.

\section{PHYSICAL MEASUREMENTS}

The hydrogen ion concentration in the dissolver solution was determined by titrating of an aliquot with standard $\mathrm{NaOH}$ after adding $17 \%$ potassium oxalate (adjusted to a pH of 5.55) to complex the uranium. Caustic solutions were titrated using standardized nitric acid. A Beckman Research Model pH Meter was used to determine the end point. Uranium concentration in the dissolver solution was determined using a Cary $14-\mathrm{H}$ spectrophotometer.

\section{IODINE COUNTING TECHNIQUES}

Iodine-125 with a half life of 60 days was supplied by New England Nuclear. The tracer was obtained in dilute sodium hydroxide solution and was added to stock feeds containing inactive iodine. Counting was performed by a RIDL 400 channel analyzer, model 24-2, which has a NaI 3-inch. crystal detector. The iodine concentration in the caustic gas trap was determined by counting an aliquot of the caustic solution for ${ }^{125} \mathrm{I}$. The $\mathrm{I}_{2}$ and organic iodides in the dissolver solution were coextracted with toluene before counting to eliminate 
the radiochemical interference of the dissolved uranium. In an attempt to determine the percent of the organic iodide in the dissolver solution, the uranium solution was adjusted with $0.2 \mathrm{M}$ hydroxylamine nitrate $\left(\mathrm{NH}_{2} \mathrm{OH} \cdot \mathrm{HNO}_{3}\right)$ prior to extraction with toluene. The results were not conclusive, and additional work is required to perfect this analysis.

Five samples containing ${ }^{129} \mathrm{I}$ and spiked ${ }^{125}$ I were counted by D. A. Dodd and C. P. McLaughl in of the Chemical Sciences Group at Rockwell Hanford Operations using a Hyper pure germanium well detector. The samples were obtained after dissolution of irradiated $\mathrm{N}$-reactor fuel in the 325-A High-Level Radiochemical Cells.

\section{RESULTS AND DISCUSSION}

Three series of tests were conducted on iodine control: (1) laboratory-scale equipment qualification studies, (2) iodine distribution studies using tracer techniques, and (3) an iodine distribution study using irradiated $N$-reactor fuel. A summary of the results of the tracer and hot-cell studies are shown in Table 1. All of the studies are discussed in more detail in the following subsections. LABORATORY EQUIPMENT QUALIFICATION STUDIES

Test 1

In the first test the dissolver, condenser, reagent addition, and air sparging systems were demonstrated. No uranium metal was added. The use of sand and a hot plate provided excellent heating of the dissolver. The iodine off-gas system consisted of two 100-ml traps containing $10 \mathrm{M} \mathrm{HNO}_{3}$ and $0.4 \underline{\mathrm{M}}$ $\mathrm{Hg}\left(\mathrm{NO}_{3}\right)_{2}$, and a caustic trap containing $100 \mathrm{ml}$ of $2 \mathrm{M} . \mathrm{VaOH}$.

Test 2

The objective of the second test was to determine the moles of nitric acid consumed per mole of uranium dissolved and to determine the effectiveness of the analytical iodine trapping system. N-reactor fuel contains approximately 14 grams of iodine per tonne of metal. This test was modified by adding a 200-fold excess of iodine to the initial dissolver acid. The excess iodine $(0.0067 \mathrm{M} \mathrm{I} / \mathrm{L}$ of final dissolver solution) was added to identify potential problems throughout the dissolver and downdraft system during dissolution of the uranium metal. 
TABLE 1: Summary of Results and Test Conditions

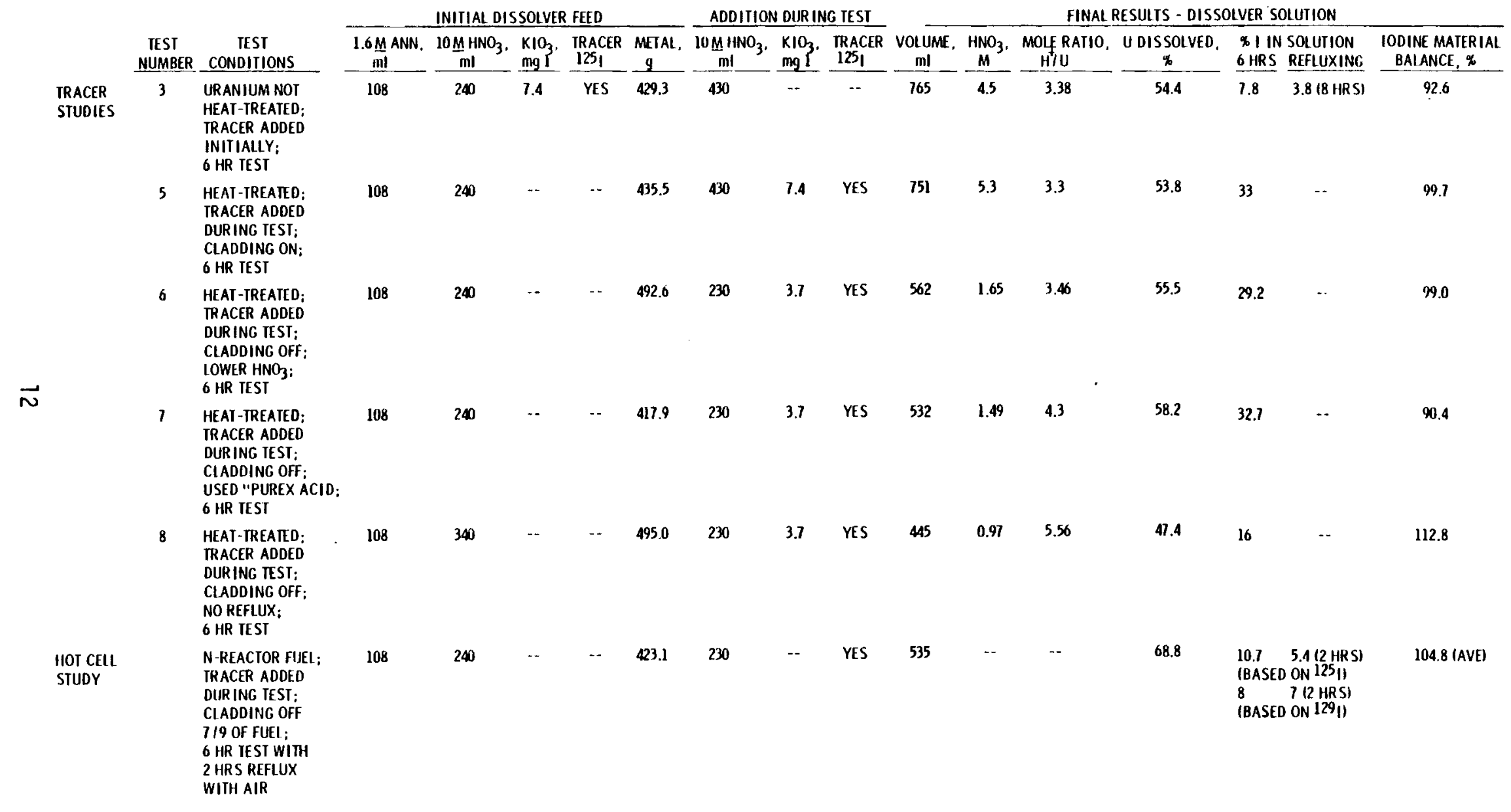


The test plan was as follows:

1. The downdraft water-cooled condenser containing glass beads was conditioned by adding $76 \mathrm{ml}$ of $\mathrm{H}_{2} \mathrm{O}$ through the top.

2. The uranium metal was cleaned using $8 \underline{\mathrm{M} H \mathrm{HNO}_{3}}+\mathrm{H}_{2} \mathrm{O}$. The oil film and uranium oxide surfaces were removed. The initial weight of the fuel was $435.6 \mathrm{~g}$ of uranium and $9.4 \mathrm{~g}$ of Zircaloy cladding.

3. The uranium metal was placed on a stainless steel grid two inches from the bottom of the dissolver.

4. The sweep air across the surface of the dissolver solution was turned on and maintained at $426 \mathrm{~cm}^{3} / \mathrm{min}$.

5. To initiate the test, $135 \mathrm{ml}$ of $1.6 \mathrm{M}$ aluminum nitrate (ANN) and 300 $\mathrm{ml}$ of $10.4 \mathrm{M} \mathrm{HNO}_{3}$ were added to the dissolver, and the sand bath was heated with the hot plate.

6. The air sparge through the bottom of the dissolver was maintained at $170 \mathrm{~cm}^{3} / \mathrm{min}$.

7. Approximately 150 min into the run, $550 \mathrm{ml}$ of $10.4 \mathrm{M} \mathrm{HNO}_{3}$ was added at $4 \mathrm{ml} / \mathrm{min}$ through a side-port in the dissolver.

8. The off-gas from the dissolver downdraft condenser system was sparged through two 100-ml bottles containing $10 \underline{\mathrm{M} \mathrm{HNO}} \mathrm{H}_{3}$ and $0.4 \mathrm{M} \mathrm{Hg}\left(\mathrm{NO}_{3}\right)_{2}$, and a third sparge bottle containing $2 \mathrm{M} \mathrm{NaOH}$. No sparge bottles were attached to the air sweep inlet (as shown in Figure 1 ).

The test was terminated after $7 \mathrm{hr}$. The dissolver solution was not removed from the dissolver for an additional $112 \mathrm{hr}$. No uranium metal was thought to be undissolved. However, when the solution was removed from the dissolver, $136.5 \mathrm{~g}$ of uranium metal (31.3\%) was found undissolved. Approximately 1.26 moles of uranium metal had been dissolved. A sample of the final $1049 \mathrm{ml}$ of dissolver solution was analyzed for $\mathrm{H}^{+}$concentration. The initial acid was also analyzed for $\mathrm{H}^{+}$concentration and was found to be $12.14 \mathrm{M}$ instead of $10.4 \mathrm{M}$ as was called for in the procedure. The initial solution contained 10.31 moles of acid, and the final dissolver solution contained 5.17 moles of $\mathrm{HNO}_{3}$. The dissolution of uranium metal using the laboratory downdraft condenser required 4.1 moles of $\mathrm{HNO}_{3}$ per mole of uranium metal. 
During test 2, the sweep air was pulled through the three gas sparge bottles

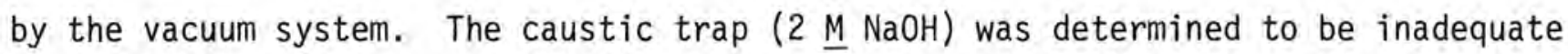
to contain the $\mathrm{NO}_{x}$ but was kept in the system during the test. A pink mercury iodine precipitate was observed inside the dry, fritted gas tube of the first bottle during the run and only partially dissolved in $10 \mathrm{M} \mathrm{HNO}_{3}-\mathrm{Hg}$ before being sampled.

The most significant observation during test 2 was the needle-like iodine crystals formed on the glass beads in the condenser and on the cool arm sticking out of the top of the dissolver at the air sweep inlet. The entire dissolver and off-gas glassware had been covered with ceramic insulation with the exception of the side arm and the water condenser. When the side arm was covered during the run, the iodine redissolved. Figure 3 shows the upper portion of the $\mathrm{H}_{2} \mathrm{O}$ condenser. The initial $I_{2}$ was observed on the upper bead surface but moved down about one inch during the $7 \mathrm{hr}$ run. Some of the crystals broke free of the mass and slowly worked their way to the bottom of the condenser. Some of the $\mathrm{I}_{2}$ redissolved and dropped back into the dissolver pot.

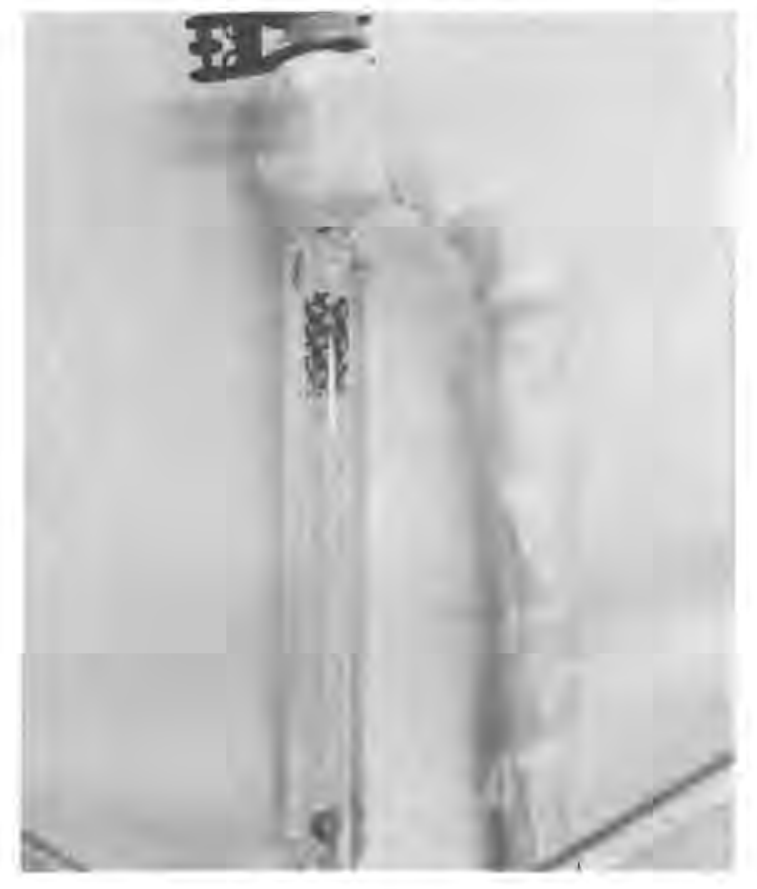

FIGURE 3: Iodine Observed in Downdraft Condenser--Test 2 


\section{Test $2 \mathrm{~A}$}

The objectives of Test $2 A$ were to: (1) repeat the Test 2 run plan, (2) reduce the iodine 50 -fold from 1.5 to $0.028 \mathrm{~g}$ of $\mathrm{KIO}_{3}$, and (3) increase the aqueous reflux condensate flow by increasing the temperature of the sand bath hot plate.

As in Test 2, black iodine crystals were observed in the top of the condenser during the first 50 min of Test $2 A$, but the crystals readily dissolved at the completion of the first hour as the condenser began to reflux. The sparge traps were constructed using coarse, fritted glass tube. The back pressure resulting from the fine frits and the increase in dissolver temperature (to force a higher reflux) resulted in a very high foam level in the dissolver which eventually spilled over into the $\mathrm{Hg}\left(\mathrm{NO}_{3}\right)_{2}$ and $\mathrm{HNO}_{3}$ trap. In addition, the sweep air flow rate became erratic, and $\mathrm{NO}_{x}$ periodically vented out of the air sweep inlet. The experiment was terminated before additional results were obtained.

\section{Test $2 \mathrm{~B}$}

The objectives of Test $2 \mathrm{~B}$ were to: (1) reduce the total dissolver solution volume from $1000 \mathrm{ml}$ in the previous tests to $800 \mathrm{ml}$, (2) replace the iodine traps using $\mathrm{Hg}-\mathrm{HNO}_{3}$ with caustic traps, and (3) guard against iodine escape from the air sweep inlet by using a caustic trap bubbler at the air inlet. To accomplish these objectives Test 2 was modified as follows:

1. First, $50 \mathrm{ml}$ of $\mathrm{H}_{2} \mathrm{O}$ was added to the dissolver through the tower to wet the glass beads.

2. Next, $428.7 \mathrm{~g}$ of uranium metal and $2.4 \mathrm{~g}$ of Zircaloy were placed in the dissolver.

3. Then, $100 \mathrm{ml}$ of $10 \mathrm{M} \mathrm{NaOH}$ was placed in the first two sparge traps and $2 \mathrm{M} \mathrm{NaOH}$ in a third trap.

4. Two traps were placed on the sweep air inlet; $200 \mathrm{ml}$ of $2 \mathrm{M} \mathrm{NaOH}$ were put in the first trap, and the second trap remained empty.

5. In order $0.028 \mathrm{~g}$ of $\mathrm{KIO}_{3}, 135 \mathrm{ml}$ of $1.6 \mathrm{M} \mathrm{ANN}$, and $300 \mathrm{ml}$ of $10.3 \mathrm{M}$ $\mathrm{HNO}_{3}$ were added to the dissolver. 
6. Air was maintained at $426 \mathrm{~cm}^{3} / \mathrm{min}$ and sparged at $170 \mathrm{~cm}^{3} / \mathrm{min}$ in the dissolver.

7. Approximately $150 \mathrm{~min}$ into the run, $350 \mathrm{ml}$ of $10.3 \mathrm{M} \mathrm{HNO}_{3}$ was added at $4 \mathrm{ml} / \mathrm{min}$.

8. The experiment was terminated after $6 \mathrm{hr}$.

A yellow color in the first caustic trap indicated that the iodine was being captured. Reducing the volume of total dissolver solution did not reduce the foam level. The sweep air flow rate continued to be erratic. The caustic trap on the air inlet did prevent the escape of $\mathrm{NO}_{x}$ and $\mathrm{I}^{-}$during high foam conditions. The parameters of test $2 \mathrm{~B}$ are listed below:

$\begin{array}{ll}\text { Initial } \mathrm{HNO}_{3} & 650 \mathrm{ml} \text { of } 9.89 \mathrm{M} \mathrm{H}^{+}(6.429 \text { moles) } \\ \text { Final } \mathrm{HNO}_{3} & 895 \mathrm{ml} \text { of } 3.97 \mathrm{M} \mathrm{H} \text { (3.586 moles) } \\ \mathrm{HNO}_{3} \text { used } & 2.84 \mathrm{moles} \\ \text { Initial weight of metal } & 428.7 \mathrm{~g} \\ \text { Final weight after } 6 \mathrm{hr} & 236 \mathrm{~g} \\ \text { Uranium dissolved } & 192.7 \mathrm{~g}(45 \%), 0.81 \text { moles } \\ \text { Mole ratio (moles } \mathrm{H}^{+} / \text {mole U) } & 3.51 \\ \text { DISTRIBUTION STUDIES USING }{ }^{125} \text { I TRACER TECHNIQUES }\end{array}$

\section{Test 3}

The objective of the first tracer study was to determine the iodine distribution in the laboratory-scale Purex dissolver and downdraft condenser. Iodine as $\mathrm{KIO}_{3}$ and tracer ${ }^{125}$ I were added to the nitric acid dissolver solution before the test began. Approximately $74 \%$ of the iodine was captured in the caustic off-gas scrub solution during the first hour of uranium metal dissolution. An additional 10\% was released to the caustic scrub during the next $5 \mathrm{hr}$ of dissolution. Approximately $8 \%$ of the iodine was found in the dissolver solution after $6 \mathrm{hr}$ of dissolution. Refluxing of the dissolver solution (no metal present) under normal dissolving conditions (Test 4) for an additional $10 \mathrm{hr}$ released an additional 4\% of the iodine. Approximately $54 \%$ of the uranium metal dissolved in $6 \mathrm{hr}$, and the mole ratio of acid consumed to metal dissolved was 3.4. An iodine material balance of $93 \%$ was achieved for the tracer experiment. 
The equipment for the tracer experiment was modified as shown in Figure 1. The frit in the caustic bubbler was replaced with extra coarse glass to reduce the back pressure experienced in the previous runs. A sample port was added to the first trap. An ice bath was added to remove condensate that had been collecting on the rotometer ball. The run plan for Test 3 was modified as follows:

1. Water was added to the top of the condenser to wet the beads and to fill the condensate return tube.

2. The uranium metal was cleaned using $\mathrm{HNO}_{3}$ and $\mathrm{H}_{2} \mathrm{O}$, and then was dried and weighed.

3. The uranium metal was placed on a stainless steel grid two inches from the bottom of the dissolver.

4. The air sweep across the surface of the dissolver solution was maintained at $426 \mathrm{~cm}^{3} / \mathrm{min}$.

5. For this experiment, $108 \mathrm{ml}$ of $1.6 \mathrm{M}$ ANN and $240 \mathrm{ml}$ of $10.16 \underline{\mathrm{M}} \mathrm{HNO}_{3}$ were added to the dissolver solution.

6. Then $7.4 \mathrm{mg}$ of iodine as $\mathrm{KIO}_{3}$ and $5 \mathrm{ml}$ of ${ }^{125} \mathrm{I}$ tracer were added to the dissolver solution.

7. The air sparge through the bottom of the dissolver was maintained at $170 \mathrm{~cm}^{3} / \mathrm{min}$.

8. Approximately 150 min into run, $430 \mathrm{ml}$ of $10.16 \mathrm{M} \mathrm{HNO}_{3}$ were added at $2.7 \mathrm{ml} / \mathrm{min}$.

9. The run was completed in $6 \mathrm{hr}$. The dissolver solution was cooled to $25^{\circ} \mathrm{C}$ within $30 \mathrm{~min}$, and all solutions were sampled.

For Test 3, N-reactor fuel that was not heat treated was used, the cladding was not removed, and the tracer was added to the dissolver before the test was started. The parameters and results of Test 3 are listed below. A breakdown of the sample analyses is given in Table 2 . 
Starting Dissolver Feed

Acid addition

Initial $\mathrm{HNO}_{3}$

Final $\mathrm{HNO}_{3}$

$\mathrm{HNO}_{3}$ used

Initial weight of metal

Final weight of metal

Uranium dissolved

Mole ratio (moles $\mathrm{H}^{+} /$mole $U$ )

Iodine in dissolver solution after $6 \mathrm{hr}$

Iodine added

Iodine material balance
$108 \mathrm{ml}$ of $1.6 \mathrm{M} \mathrm{HNO}_{3} ; 240 \mathrm{ml}$ of $9.89 \mathrm{M} \mathrm{HNO}_{3} ; 0.5 \mathrm{ml}$ of $25 \mathrm{~g}$ $\mathrm{KIO}_{3} /\left[\mathrm{L}(7.4 \mathrm{mg} \mathrm{I}) ; 5 \mathrm{ml}\right.$ of $125_{\mathrm{I}}$ tracer

$430 \mathrm{ml}$ of $9.89 \mathrm{M} \mathrm{HiNO}_{3}$

$670 \mathrm{ml}$ of $10.16 \mathrm{M} \mathrm{H}^{+}+765 \mathrm{ml}$ of $4.51 \mathrm{M} \mathrm{H}^{+}(3.5$ moles $)$

3.3 moles

$429.3 \mathrm{~g}$ (not heat-treated, zirconium clad)

$195.7 \mathrm{~g}$

$233.6 \mathrm{~g}(54 \%)$ (0.98 moles)

3.4

$7.8 \%$

$7.4 \mathrm{mg} \mathrm{I} / 233.6 \mathrm{~g} \mathrm{U}$ dissolved $=$ $31.7 \mathrm{~g} \mathrm{I} /$ tonne U

$92.6 \%$

Test 4

Two weeks after completion of Test 3 , the dissolved uranium solution was reanalyzed for ${ }^{125} \mathrm{I}$. The $750 \mathrm{ml}$ of solution containing $4.5 \mathrm{M} \mathrm{H}^{+}$and $1.28 \mathrm{MU}(V I)$ had not lost iodine to the atmosphere during storage. The solution was placed in the dissolver vessel and heated to $95^{\circ}$ to $105^{\circ} \mathrm{C}$ as in Test 3 (no uranium metal present). The caustic trap was sampled each hour to determine the loss of iodine to the sparge and sweep air. After $8 \mathrm{hr}$ of refluxing, $45 \%$ of the remaining iodine ( $4 \%$ of the initial Test 3 ) was released to the caustic trap. The results are shown in Table 3 .

\section{Test 5}

Test 3 was completed by adding all of the ${ }^{125}$ I tracer to the dissolver solution before the experiment was initiated. However, in reality, the iodine from spent $\mathrm{N}$-reactor fuel is released as a function of uranium dissolution. Therefore, Test 5 was designed to simulate iodine release with uranium 
TABLE 2: Summary of Uranium Metal Dissolution -- Test 3

\begin{tabular}{|c|c|c|c|c|c|}
\hline & Time, & Test & $\begin{array}{l}\% \text { of } \\
\text { Initial }\end{array}$ & $\begin{array}{r}\mathrm{H}^{+} \mathrm{O} \\
\text { Conce }\end{array}$ & $\begin{array}{l}\left.\mathrm{H}^{-}\right) \\
\text {tion } \\
\end{array}$ \\
\hline Sample & $\min$. & Volume, ml & & Initial & Final \\
\hline First Caustic Trap & & & & & \\
\hline 1 & 60 & 135 & 73.5 & (10) & \\
\hline 2 & 120 & 140 & 80.1 & & \\
\hline 3 & 180 & 145 & 80.1 & & \\
\hline 4 & 240 & 150 & 82.8 & & \\
\hline 5 & 300 & 155 & 83.0 & & \\
\hline 6 & 360 & 161 & 84.1 & (10) & 1.91 \\
\hline Second Caustic Trap & 360 & 100 & 0.44 & (10) & $(10)$ \\
\hline Condensate Return $(\mathrm{a})$ & 360 & 5 & 0.28 & -- & 8.77 \\
\hline Air Inlet Trap & 360 & 200 & 0 & (10) & $(10)$ \\
\hline Dissolver Solution & 360 & 765 & 7.8 & 8.9 & 4.51 \\
\hline $\begin{array}{l}\text { Initial Dissolver } \\
\text { Solution Spike }\end{array}$ & & 5 & & & \\
\hline Total recovery & & & 92.6 & & \\
\hline
\end{tabular}

(a) Contained $4 \mathrm{ml}$ of acid; $1 \mathrm{ml}$ of acid was assumed to be still on the beads.

TABLE 3: Loss of Iodine from a Dissolver Solution with Refluxing and Air Sparging as a Function of Time

\begin{tabular}{ll} 
Time, & $\begin{array}{c}\text { \% of Iodine } \\
\text { in Dissolver Solution } \\
\text { Sample }\end{array}$ \\
\hline
\end{tabular}

First Caustic Trap

\begin{tabular}{|c|c|c|}
\hline 1 & 60 & $0.4^{(a)}$ \\
\hline 2 & 115 & 8.7 \\
\hline 3 & 188 & 20.9 \\
\hline 4 & 240 & 27.9 \\
\hline 5 & 310 & 34.4 \\
\hline 6 & 410 & 39.6 \\
\hline 7 & 480 & 45.5 ( $4 \%$ of initial Test 3 iodine) \\
\hline Second Caustic Trap & 480 & 0.01 \\
\hline Condensate Return, $5 \mathrm{ml}$ & 480 & $1.0\left(\mathrm{H}^{+}, 0.17\right)$ \\
\hline
\end{tabular}


dissolution by adding the ${ }^{125} \mathrm{I}$ tracer with the $\mathrm{HNO}_{3}$ addition continuously throughout the $6 \mathrm{hr}$ run. In addition, there was an interest in obtaining uranium metal dissolution data as a function of time during Test 5 . Because of the uneven pitting of the metal surface during dissolution, heat-treated metal was used for Test 5 and all subsequent tests. Approximately $33 \%$ of the iodine remained in the dissolver solution after $6 \mathrm{hr}$ compared to $8 \%$ when the tracer was added to the initial dissolver solution. The mole ratio of acid consumed to metal dissolved was 3.3, with $54 \%$ of the uranium dissolved. Uranium and acid concentration in the dissolver solution were determined as a function of time. The parameters and results of Test 5 are listed below. A more detailed breakdown of the results is given in Table 4 .

Starting dissolver feed

Acid addition

Initial $\mathrm{HNO}_{3}$

Final $\mathrm{HNO}_{3}$

$\mathrm{HNO}_{3}$ Used

Initial weight of metal

Final weight of metal

Uranium dissolved.

Mole ratio (moles $\mathrm{H}^{+}$/mole $\mathrm{U}$ )

Iodine in dissolver solution after $6 \mathrm{hr}$

Iodine material balance

Iodine added

Surface area of metal
$108 \mathrm{ml}$ of $1.6 \underline{M}$ ANN; $240 \mathrm{ml}$ of $10.86 \underline{M}$ $\mathrm{HNO}_{3}$.

$430 \mathrm{ml}$ of $10.86 \mathrm{M} \mathrm{HNO}_{3} ; 5 \mathrm{ml}$ of ${ }^{125} \mathrm{I}$ tracer; $0.5 \mathrm{ml}$ of $25 \mathrm{~g} \mathrm{KIO}_{3} / \mathrm{L}(7.4 \mathrm{mg} \mathrm{I})$; addition rate $=1.24 \mathrm{ml} / \mathrm{min}$.

$670 \mathrm{ml}$ of $10.86 \mathrm{M} \mathrm{HNO}_{3} \quad(7.28$ moles)

$751 \mathrm{ml}$ of $5.3 \mathrm{MHO}_{3}+5 \mathrm{ml}$ of $6.4 \mathrm{M} \mathrm{HNO}_{3}$ $(4.0 \text { moles })^{-}$

3.27 moles

$435.3 \mathrm{~g}$ (4 pieces, zirconium clad on two faces)

$201.2 \mathrm{~g}$

$234.3 \mathrm{~g}(54 \%)(0.984$ moles $)$

3.3

$31.7+1.3 \%(33 \%)$

$99.7 \%$

$7.4 \mathrm{mg} \mathrm{I} / 234.3 \mathrm{~g} \mathrm{U}$ dissolved (31.6 g I/tonne)

6.688 in $^{2}$ to 5.089 in $^{2}$ after dissolution 
TABLE 4: Summary of Uranium Metal Dissolution -- Test 5

Sampling Time, $\mathrm{hr}$

\begin{tabular}{ccccccc} 
Sampling Time, hr \\
\hline 1 & 2 & 3 & 4 & 5 & 6 & Final \\
\hline
\end{tabular}

Dissolver

Solution

$\%$ Iodine

$\mathrm{H}^{+}, \underline{M}$

$U, g / L$

Volume, $\mathrm{ml}$
88.3

7.2

49.0

488.1
$42.8(?) \quad 34.9$

36.0

6.2

6.4

5.9

32.5

30.95

31.66

146.0

198.0

224.0

5.6

5.5

5.3

540.7 593.2

284.0

326.0

328.0

645.8

$698.4 \quad 751.0$

751.0

First Caustic

Trap

$$
\begin{aligned}
& \% \text { Iodine } \\
& \mathrm{OH}^{-}, \mathrm{M}
\end{aligned}
$$

13.3

17.3

59.6

Volume, $\mathrm{ml}$

8.6

135

Second Caustic

Trap

$\%$ Iodine

$\mathrm{OH}^{-}, \underline{\mathrm{M}}$

Volume, $\mathrm{ml}$

7.4

5.5

58.0

59.5

61.7

66.5

139

144

4.2

3.2

2.1

2.0

Backup Trap

$\%$ Iodine

$\mathrm{OH}^{-}, \underline{\mathrm{M}}$

Volume, $\mathrm{ml}$

$\begin{array}{ccccccc}-- & -- & -- & -- & -- & -- & 0.23 \\ -- & -- & -- & -- & -- & -- & 8.0 \\ 100 & 100 & 100 & 100 & 100 & 100 & 104\end{array}$

-Tube

$$
\% \text { Iodine }
$$

$\mathrm{H}^{+}, \underline{\mathrm{M}}$

Volume, $\mathrm{ml}$

$\%$ Iodine $^{(b)}$

Recovered

$\begin{array}{ccccccc}-- & -- & -- & -- & -- & & 0 \\ -- & -- & -- & -- & -- & -- & 9.3 \\ 100 & 100 & 100 & 100 & 100 & 100 & 96\end{array}$

(a) Washed downdraft column and $U$ tube to remove all iodine and $\mathrm{HNO}_{3}$.

(b) \% of available iodine with time. 


\section{Test 6}

Test 6 was completed to determine the effect of a lower acid concentration on the release of iodine. In addition, the cladding was removed from the uranium to more nearly represent flowsheet conditions. Iodine tracer and $\mathrm{HNO}_{3}$ acid were added continuously throughout the test; other conditions were similar to Test 5 . Approximately $30 \%$ of the jodine remained in the dissolver solution after $6 \mathrm{hr}$. The final dissolver solution contained $2 \underline{\mathrm{M}}$ uranium and $1.65 \underline{\mathrm{M}} \mathrm{H}^{+}$. The acid consumed was 3.5 moles per mole of dissolved uranium. The $0.95 \%$ enriched, heat-treated, $\mathrm{N}$-reactor uranium metal was weighed and measured before and after dissolution. The final material balance was $99 \%$. The test parameters and results for Test 6 are listed below. A more detajled breakdown of the results is given in Table 5 .

Starting dissolver feed

Acid addition

Initial $\mathrm{HNO}_{3}$

Final $\mathrm{HNO}_{3}$

$\mathrm{HNO}_{3}$ used

Initial weight of metal

Final weight of metal

Uranium dissolved

Mole ratio (moles $\mathrm{H}^{+}$/mole $U$ )

Iodine in dissolver solution after $6 \mathrm{hr}$

Iodine added

Iodine material balance
$108 \mathrm{ml}$ of $1.6 \mathrm{M} \mathrm{ANN} ; 240 \mathrm{ml}$ of $10.52 \mathrm{M} \mathrm{HNO}_{3}$ $230 \mathrm{ml}$ of $10.52 \mathrm{M} \mathrm{HNO}_{3} ; 5 \mathrm{ml}$ of ${ }^{125} \mathrm{I}$ tracer; addition rate $=0.695 \mathrm{ml} / \mathrm{min}$.

$470 \mathrm{ml}$ of $10.52 \mathrm{M} \mathrm{H}^{+}$(4.94 moles)

$562 \mathrm{ml}$ of $1.65 \underline{\mathrm{MH}} \mathrm{H}^{+}+31 \mathrm{ml}$ of $1.65 \mathrm{M} \mathrm{H}^{+}$ (0.98 moles)

3.97 moles

$942.6 \mathrm{~g}$ ( 5 pieces, no zirconium clad)

$219.3 \mathrm{~g}$

$273.3 \mathrm{~g}(55.5 \%)(1.148 \mathrm{moles})$

\subsection{6}

$24.1 \%+5.8 \%(29.9 \%)$

$3.7 \mathrm{mg} \mathrm{I} / 273.3 \mathrm{~g} \mathrm{U}$ dissolved $=13.5 \mathrm{~g}$ I/tonne U

$99 \%$ 
TABLE 5: Summary of Uranium Metal Dissolution -- Test 6

Sampling Time, $\mathrm{hr}$

\begin{tabular}{lllllll}
\hline 1 & 2 & 3 & 4 & 5 & 6 & Final \\
\hline
\end{tabular}

Dissolver

Solution

$\%$ Iodine

$\mathrm{H}^{+}, \underline{\mathrm{M}}$

$U, g / L$

Volume, $\mathrm{ml}$
21.9

8.3

153

\section{Trap
$\%$ Iodine
$\mathrm{OH}^{-}$or $\left(\mathrm{H}^{+}\right)$,
Volume, $\mathrm{ml}$
Second Caustic
Trap \\ Trap
$\%$ Iodine
$\mathrm{OH}^{-}$or $\left(\mathrm{H}^{+}\right), \mathrm{M}$
Volume, $\mathrm{mr}$
Second Caustic
Trap \\ Trap
$\%$ Iodine
$\mathrm{OH}^{-}$or $\left(\mathrm{H}^{+}\right)$,
Volume, $\mathrm{ml}$
Second Caustic
Trap \\ Trap
$\%$ Iodine
$\mathrm{OH}^{-}$or $\left(\mathrm{H}^{+}\right)$,
Volume, $\mathrm{ml}$
Second Caustic
Trap \\ Trap
$\%$ Iodine
$\mathrm{OH}^{-}$or $\left(\mathrm{H}^{+}\right)$,
Volume, $\mathrm{ml}$
Second Caustic
Trap}

$\%$ Iodine

$\mathrm{OH}^{-}, \mathrm{M}$

VoT ume, ml

Backup Trap

$\%$ Iodine

$\mathrm{OH}^{-}, \underline{\mathrm{M}}$

Volume, ml

Uranium Tube

$$
\begin{aligned}
& \% \text { Iodine } \\
& H^{+}, M \\
& \text { Vol ume, } \mathrm{ml} \\
& \% \text { Iodine } \\
& \text { Recovered }
\end{aligned}
$$

85.9

39.5

5.7

37.2

8.2

38

356.7
198

384
3.6

332

419

--
--
100

$50.2 \quad 49.9$

55.1

32.8

31.0

28.3

24.1

2.6

2.6

1.7

1.65

414

452

496

512

455

526

562

562

First Caustic

(a) Spilled Bubbler \#1 into \#2 during cooling of dissolver solution.

(b) Washed downdraft condenser and column uranium tube to remove all I and $\mathrm{HNO}_{3}$.

(c) \% of available iodine with time. 
TABLE 6: Physical Measurements of 0.95\% Enriched Inner N-Reactor Fuel -- Before and After Dissolution Test 6

Measurement Before and After Dissolution

Fuel Piece

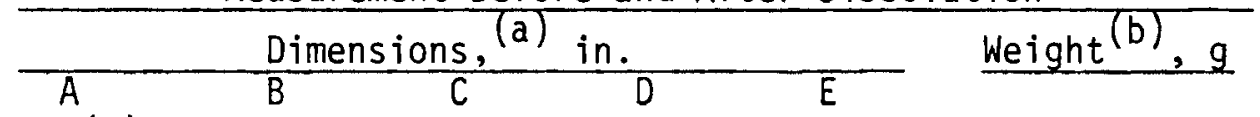

$1-1.2(\mathrm{c})$

1.2 (c) $\quad 0.515$

0.755

0.346

0.591

96.0

1.055

0.585

0.573

0.244

0.435

46.3

2

1.2

0.515

0.729

0.352

0.591

0.255

0.450

103.2

3

1.2

0.515

0.610

0.346

0.591

43.0

1.089

0.585

0.778

0.262

0.450

98.7

4

1.28

0.515

0.727

0.344

0.591

0.264

0.466

42.3

5

1.2

0.515

0.585

0.764

0.354

0.578

0.243

0.591

0.437

95.0

45.4

99.4

42.3

(a) The dimensions ( $A, B, C, D$, and $E$ ) that were measured are indicated below.

(b) Initial weight of five pieces of metal $=492.6 \mathrm{~g}$; the final weight after $6 \mathrm{hr}$ of dissolution $=219.3 \mathrm{~g}$.

(c) The top number is the "before" measurement, and the bottom number is the "after" measurement.

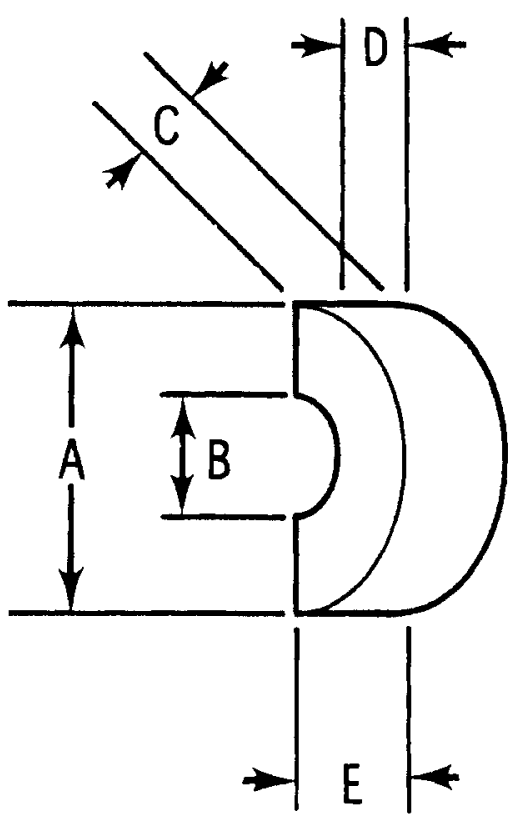




\section{Test 7}

Recycled acid from the Purex plant may contain organic acids that could increase the formation of organic iodine compounds when recycled back to the dissolver. In an attempt to address this problem, a sample of Purex recycled acid was analyzed by the Rockwell Hanford Operations analytical laboratory (see Experimental section). The acid was then adjusted to $10 \mathrm{M} \mathrm{HNO}_{3}$ (468 $\mathrm{ml}$ of Purex acid $+532 \mathrm{ml}$ of $15.7 \mathrm{M} \mathrm{HNO}_{3}$ ) and was used in Test 7 . No major differences were noted between Test 6 and Test 7. Approximately 33\% of the iodine was found in the final dissolver solution. A change in procedure in heating the dissolver with glycol (an initial temperature of $97^{\circ} \mathrm{C}$ instead of the sand bath at $25^{\circ} \mathrm{C}$ ) increased the uranium metal dissolution rate in the first hour. In addition, the cooling $\mathrm{H}_{2} \mathrm{O}$ in the downdraft water jacket was not turned on during the first $2 \mathrm{hr}$ resulting in a premature neutralization of the first caustic trap, a release of iodine into the second trap, and an overall increase in $\mathrm{HNO}_{3}$ consumption.

The $\mathrm{HNO}_{3}$ consumed during Test 7 was 4.2 moles of $\mathrm{H}^{+}$per mole of uranium metal dissolved. The $0.95 \%{ }^{235} \mathrm{U}$ metal, heat-treated, $\mathrm{N}$-reactor uranium was weighed before and after dissolution. Iodine results were obtained for the dissolver, the first and second traps, and the uranium return tube each hour during dissolution. The final iodine material balance was $90.5 \%$. The parameters and results of Test 7 are listed below. A more detailed breakdown of the results is given in Table 7 .

Starting dissolver feed

Acid addition

Initial $\mathrm{HNO}_{3}$
Final $\mathrm{HNO}_{3}$

$\mathrm{HNO}_{3}$ used

Initial weight of metal

Final weight of metal

Uranium dissolved

Mole ratio (moles $\mathrm{H}^{+} /$mole $U$ )

Iodine in dissolver solution after $6 \mathrm{hr}$

Iodine added

Iodine material balance
$108 \mathrm{ml}$ of $1.6 \mathrm{M}$ ANiv; $240 \mathrm{ml}$ of Purex Acid

$230 \mathrm{ml}$ of Purex Acid; $5 \mathrm{ml}$ of ${ }^{125} \mathrm{I}$ tracer; $0.24 \mathrm{ml}$ of $25 \mathrm{~kg} \mathrm{KIO} / \mathrm{L}(3.7 \mathrm{mg} \mathrm{I})$; addition rate $=0.62 \mathrm{ml} / \mathrm{min}$.

$470 \mathrm{ml}$ of $10.86 \mathrm{M} \mathrm{H}^{+}$(5.10 moles)

$532 \mathrm{ml}$ of $1.49 \mathrm{M} \mathrm{H}^{+}+6 \mathrm{ml}$ of $10.28 \mathrm{M} \mathrm{H}^{+}$ (0.85 moles)

4.25 moles

$417.9 \mathrm{~g}$ ( 6 pieces, zirconium removed)

$174.5 \mathrm{~g}$

$243.4 \mathrm{~g}(58.2 \%)(1.02$ moles $)$

4.2

$24.8 \%+7.9 \%=32.7 \%$

$3.7 \mathrm{mg} \mathrm{I} / 243.4 \mathrm{~g} \mathrm{U}$ dissolved $=15.2 \mathrm{~g} \mathrm{I} /$ tonne $90.4 \%$ 
TABLE 7: Summary of Uranium Metal Dissolution -- Test 7

Sampling Time, $h r$

\begin{tabular}{llllll}
\hline 1 & 2 & 3 & 4 & 5 & 6.25 \\
\hline
\end{tabular}

Dissolver

Solution

$\begin{array}{lcccccc}\text { \% Iodine } & 54.3 & 36.4 & 25.6 & 20.2 & 17.4 & 24.8 \\ \mathrm{H}^{+}, \underline{\mathrm{M}} & 4.6 & 2.89 & 1.96 & 1.6 & 1.3 & 1.49 \\ \mathrm{U}, \mathrm{g} / \mathrm{L} & 238 & 310 & 370 & 440 & 440 & 450 \\ \text { Volume, } \mathrm{ml} & 375 & 410 & 440 & 470 & 500 & 532\end{array}$

First Caustic

Trap

$\begin{array}{lcccccc}\text { \% Iodine } & 61.1 & 62.7 & 60.6 & 56.3 & 41.1 & 33.7 \\ \mathrm{OH}^{-} \text {or }\left(\mathrm{H}^{+}\right), \underline{M} & 2.67 & 0.17 & 0.12 & 0.07 & (0.38) & (0.77) \\ \text { Volume, } \mathrm{ml} & 115 & 130 & 132 & 134 & 136 & 136\end{array}$

Second Caustic

Trap

$\begin{array}{lcccccc}\text { \% Iodine } & 0.4 & 6.1 & 10.5 & 13.5 & 13.2 & 23.1 \\ \mathrm{OH}^{-} \text {or }\left(\mathrm{H}^{+}\right), \mathrm{M} & 9.26 & 9.14 & 8.0 & 6.9 & 5.39 & 4.99 \\ \text { Volume, } \mathrm{ml} & 100 & 100 & 101 & 102 & 103 & 103\end{array}$

Backup

Trap

$\%$ Iodine

$\mathrm{OH}^{-}, \underline{\mathrm{M}}$

Volume, $\mathrm{ml}$

Uranium Tube

$\%$ Iodine

$\mathrm{H}^{+}, \underline{\mathrm{M}}$

Volume, $\mathrm{ml}$

$\%$ Iodine $(c)$
Recovered

123

7.0

$12.5 \quad 10.3$

12.35

11.05

6

6

6

$118 \quad 107$

$\begin{array}{lll}-- & - \\ -- & - & - \\ - & -\end{array}$

$0.84^{(a)}$

192

(a) Plugging in the second trap caused a gas backup during run.

(b) Washed downdraft condenser and column uranium tube to remove all I and $\mathrm{HNO}_{3}$.

(c) \% of available iodine with time. 
Test 8

Test 8 was designed to determine the iodine remaining in the dissolver solution after $6 \mathrm{hr}$ of dissolution without recycling the acid condensate $\left(20.01 \mathrm{~g} \mathrm{I} / \mathrm{L}\right.$ of $\left.210 \mathrm{M} \mathrm{HNO}_{3}\right)$. Previous tests (5 through 8 ) showed that $232 \%$ of the iodine remained in the dissolver solution, including $5 \%$ that was found in the acid held up in the return leg of the dissolver from the reflux condenser. Therefore, the test glassware was modified by cutting the glass tube return to the dissolver. Additional acid was added to the dissolver throughout the 6-hr uranium dissolution to compensate for the loss of the reflux acid.

Approximately $16 \%$ of the iodine remained in the dissolver solution after $6 \mathrm{hr}$ of dissolution. Eliminating the recycled acidic condensate reduced the iodine found in the final dissolver solution by $50 \%$. The final dissolver solution contained $2.1 \mathrm{MU}$ and $0.97 \mathrm{M} \mathrm{H}^{+}$. The acid consumed was 5.56 moles of $\mathrm{H}^{+}$per mole of uranium dissolved. Approximately $47 \%$ of the metal dissolved. The final iodine material balance was $112.8 \%$. The dissolver solution was refluxed at $100^{\circ} \mathrm{C}$ with air sparging for an additional $6 \mathrm{hr}$ without a significant reduction in iodine. After $6 \mathrm{hr}$ of metal dissolution and $6 \mathrm{hr}$ of refluxing, $12.5 \%$ of the iodine remained in the dissolver solution. The parameters and results of Test 8 are listed below. A more detailed breakdown of the results is given in Table 8 .

Starting dissolver feed

Acid addition

Initial $\mathrm{HNO}_{3}$

Final $\mathrm{HNO}_{3}$

$\mathrm{HNO}_{3}$ used

Initial weight of metal

Uranium dissolved

Mole ratio (moles $\mathrm{H}^{+}$/mole $U$ )

Iodine in dissolver solution after $6 \mathrm{hr}$

Iodine added

Iodine material balance
$108 \mathrm{ml}$ of $1.6 \mathrm{M} \mathrm{ANN} ; 340 \mathrm{ml}$ of $10.38 \mathrm{MHNO}_{3}$

$230 \mathrm{ml}$ of $10.38 \mathrm{M} \mathrm{HNO}_{3} ; 5 \mathrm{ml}$ $25 \mathrm{~g} \mathrm{KIO}_{3} / \mathrm{L}$ (3.7 $\left.\mathrm{mg} \mathrm{I}\right)$; addition rate was not constant during run. $570 \mathrm{ml}$ of $10.38 \mathrm{M} \mathrm{H}^{+}$(5.92 moles) $445 \mathrm{ml}$ of $0.97 \mathrm{M} \mathrm{H}^{+}$(0.43 moles) 5.49 moles $260.2 \mathrm{~g}$

$234.8 \mathrm{~g}(47.4 \%)(0.986 \mathrm{moles})$

5.56

$16.2 \%$ (after $6 \mathrm{hr}$ of refluxing $=$ $12.5 \%)$

$3.7 \mathrm{mg} \mathrm{I} / 234.8 \mathrm{~g} \mathrm{U}$ dissolved $=15.8 \mathrm{~g}$ I/tonne

$112.8 \%$ 
TABLE 8: Summary of Uranium Metal Dissoiution -- Test 8

Sampling Time, $\mathrm{hr}$

\begin{tabular}{llllll}
\hline 1 & 2 & 3 & 4 & 5 & 6 \\
\hline
\end{tabular}

Dissolver

Solution

$\begin{array}{lcccccc}\text { \% Iodine } & 8.8 & 14.8 & 19.5 & 16.4 & 15.7 & 16.2 \\ \mathrm{H}^{+}, \mathrm{M} & 6.15 & 3.12 & 1.94 & 1.08 & 0.94 & 0.97 \\ \mathrm{U}, \mathrm{g} / \mathrm{L} & 104 & 238 & 384 & 455 & 480 & 505 \\ \text { Volume, } \mathrm{ml} & 461 & 426 & 419 & 420 & 428 & 445\end{array}$

First Caustic

Trap

$\begin{array}{lcccccc}\text { \% Iodine } & 3.3 & 15.8 & 20.3 & 35.9 & 37.3 & 38.0 \\ \mathrm{OH}^{-}, \mathrm{M} & 5.27 & 1.97 & 0.41 & 0.18 & 0.19 & 0.18 \\ \text { Volume, } \mathrm{ml} & 105 & 110 & 115 & 120 & 125 & 128\end{array}$

Second Caustic

Trap

$\begin{array}{lcccccc}\text { \% Iodine } & 1.5 & 7.1(?) & 0.2 & 3.0 & 4.5 & 6.1 \\ \mathrm{OH}^{-}, \mathrm{M} & 9.52 & 9.55 & 9.24 & 8.10 & 8.03 & 7.20 \\ \text { Volume, ml } & 100 & 100 & 100 & 100 & 100 & 100\end{array}$

Backup Trap

$\%$ Iodine

$\mathrm{OH}^{-}, \underline{\mathrm{M}}$

Volume, $\mathrm{ml}$

$--$

$\begin{array}{rrrrr}-- & -- & -- & -- & 0.5 \\ -- & -- & -- & -- & 10 \\ 25 & 125 & 125 & 125 & 125\end{array}$

\section{Condensate}

Recovered

During $\Delta T$ (Total)

$\%$ Iodine

$\mathrm{H}^{+}, \underline{\mathrm{M}}$

1.3

9.4

(10.7)

15.9

$(25.6) \quad(37.0)$

7.9
$(44.9)$

7.1

$$
11.72
$$

10.11

10.52

9.33

$\begin{array}{ll}(10.50) \quad(10.26) & 0\end{array}$

9.22

$(52.0)$

Volume, $\mathrm{ml}$

(11.72)

(10.48)

40.5

69.0
$(39.6)$

(130.1)

32.0

$(10.12)$

8.80

20.6
$(20.6)$

(162.1)

25.9

$\%$ Iodine

14.9

48.4

66.6

92.3

102.4

112.8

(a) \% of available iodine with time. 
IODINE DISTRIBUTION STUDY USING IRRADIATED N-REACTOR FUEL

A proof-of-principle dissolution study was attempted using irradiated $\mathrm{N}$-reactor fuel and a previously tested laboratory-scale downdraft condenser and dissolver that was in the 325-A High Level Radiochemistry facility, 325 Building, 300 Area. The fuel was received as $80-g$ half-circles of uranium metal with cladding on the curved inner and outer surfaces. The zirconium cladding was dissolved with $\mathrm{NH}_{4} \mathrm{~F}_{-} \mathrm{NH}_{4} \mathrm{NO}_{3}$ and nine half-circles of metal (423 g) were suspended in the lower portion of the dissolver from a stainless steel screen basket and wire. The dissolution procedure was similar to the previous tracer tests. Nitric acid containing ${ }^{125}$ I tracer was added continuously during the 6 -hr test; this was followed by $2 \mathrm{hr}$ of refluxing with air sparging. The objective of the test was to compare the iodine tracer studies using unirradiated and irradiated fuel with iodine found as a fission product $\left({ }^{129} \mathrm{I}\right)$ in the irradiated fuel.

Approximately $11 \%$ and $6 \%$ of the initial ${ }^{129}$ I tracer was found in the dissolver solution after 6 and $8 \mathrm{hr}$, respectively. An iodine material balance of $105 \%$ was achieved for the irradiated fuel experiment. Fission product ${ }^{129}$ I results for the irradiated fuel test duplicated the tracer study with $8 \%$ and $7 \%$ of the iodine remaining in the dissolver solution after 6 and $8 \mathrm{hr}$, respectively. Approximately 1,012 $\mathrm{pCi}$ of ${ }^{129}$ I were found per $\mathrm{g}$ of $\mathrm{N}$-reactor fuel dissolved. The tracer and fission product iodine results do not agree with unirradiated uranium metal dissolution tests, which showed approximately $30 \%$ of the iodine remaining in the dissolver solution after $6 \mathrm{hr}$ of dissolution. The parameters and results of the irradiated fuel dissolution test are listed below. A breakdown of the iodine analysis is given in Table 9.

Starting dissolver feed

Acid addition

Initial weight of metal

Final weight of metal

Uranium dissolved
$108 \mathrm{ml}$ of $1.6 \mathrm{M} \mathrm{ANN} ; 240 \mathrm{ml}$ of $10 \mathrm{M} \mathrm{HNO}_{3}$

$230 \mathrm{ml}$ of $10 \underline{\mathrm{M} \mathrm{HNO}} 3 \mathrm{HN}_{3} ; 5 \mathrm{ml}$ of ${ }^{125} 5_{\mathrm{I}}$ tracer

$423.1 \mathrm{~g}$ ( 9 pieces, zirconium removed from 7)

$132.1 \mathrm{~g}$

$291.0 \mathrm{~g}(69 \%)(1.22 \mathrm{moles})$ 
TABLE 9: The Results of the Iodine Analyses for the N-Reactor Fuel Dissolution Test

Sample and Time Sample Taken

Dissolver solution, $6 \mathrm{hr}$

Dissolver solution, $8 \mathrm{hr}$

Caustic gas trap, $8 \mathrm{hr}$

Iodine material balance, $8 \mathrm{hr}$

\begin{tabular}{|c|c|c|c|}
\hline \multicolumn{4}{|c|}{$\frac{\text { Amount of Iodine Found }}{225 \text { (a) }}$} \\
\hline${ }^{125} \mathrm{I}, \%$ & $125 \mathrm{I}, \%$ & ${ }^{129} \mathrm{I}, \%$ & $129 \mathrm{I}, \mathrm{pCi} / \mathrm{g}$ \\
\hline 12.0 & 9.4 & 8 & 81.8 \\
\hline 4.9 & 6.0 & 7 & 72.6 \\
\hline 98.7 & 99.9 & 93 & 939.2 \\
\hline 103.6 & 105.9 & 100 & 1011.8 \\
\hline
\end{tabular}

\section{CONCLUSIONS}

Laboratory and hot-cell studies indicate that the Purex plant cannot meet the goal of less than $1 \%$ of the iodine remaining in the dissolver solution after acid dissolution of uranium metal $\mathrm{N}$-reactor fuel. Methods are needed for enhancing iodine evolution.

The laboratory-scale dissolver/downdraft condenser was successfully tested for use in the Purex plant simulation studies. Approximately $8 \%$ of the iodine remained in the dissolver solution after $6 \mathrm{hr}$ of uranium metal dissolution. Four additional ${ }^{125}$ I tracer studies were completed prior to the proof-of-principle dissolution study using irradiated $N$-reactor fuel. These studies were modified to permit the cold iodine $\left(\mathrm{KIO}_{3}\right)$ and ${ }^{125}$ I tracer to be added to the dissolver solution as a function of time, simulating the release of iodine with uranium metal dissolution. Approximately $30 \%$ of the iodine remained in solution after $6 \mathrm{hr}$ of dissolution.

When irradiated $\mathrm{N}$-reactor fuel was dissolved, ${ }^{125}$ I tracer was again added to the dissolver solution as a function of time. The tracer ${ }^{125} \mathrm{I}$ and the fission product ${ }^{129}$ I results showed that $11 \%$ to $8 \%$ of the iodine remained in the dissolver solution after $6 \mathrm{hr}$ of dissolution. After $2 \mathrm{hr}$ of air sparging, $6 \%$ of the ${ }^{125} \mathrm{I}$ and $7 \%$ of the fission product ${ }^{129} \mathrm{I}$ remained in solution. 


\section{BIBLIOGRAPHY}

Eggleton, A. F. J., and D. H. F. Atkins. 1964. "The Identification of Trace Quantities of Radioactive Iodine Compounds by Gas-Chromatographic and Effusion Methods." Radio Chimica Acta. 3(3):151-158.

Haller, W. H., and R. W. Perkins. 1967. "Organic Iodine-131 Compounds Released from a Nuclear Fuel Chemical Process Plant." Health Physics. 13:733-738.

Holm, C. H., 1951a. Retention of Iodine in Process Solutions by Mercuric Salts, HW-21103, General Electric Co., Richland, AEC, Richland, WA 99352.

Holm, C. H., 1951b. Residual of Iodine from Aqueous Solutions by Sparging. HW-20803, General Electric Co., Richland, AEC, Richland, WA 99352.

Jeppson, D. W. 1976. Program for Control of Iodine-129 During Zirconium Clad Fuel Reprocessing at Purex. ARH-CD-583, Atlantic Richfield Hanford Co., ERDA Richland, WA 99352 .

Mailen, J. C., and D. E. Horner. 1977. "Removal of Iodine from Reactor Fuel Solutions as Insoluble Pd I2," Nuclear Technology. 33: 260-263.

Numakura, K., M. Saeki, and E. Tachikawa. 1973. "Method for Suppressing Formation of Organic Iodides by Reaction of Carrier-Free Iodine-131 in $\mathrm{HNO}_{3}$ Solutions." Journal of Nuclear Science and Technology. 10(12):762-764.

Saeki, M., K. Numakura, and E. Tachikawa. 1974. "Carbon Sources and Formation Mechanisms of Organic Iodides in Nitric Acid Solutions." International Journal of Applied Radiation and Isotopes. 25:407-414.

Schmidt, W. C. 1975. Laboratory Programs - Dissolver Iodine Split, HW-4949A, General Electric Co., AEC, Richland, WA 99352.

Sheldon, E. B., 1977. Experience with Processing Irradiated Fuel at the Savannah River Plant (1954-1976), DP-1467, E. I. DuPont deNemours and Company, Aiken, S C 29801.

Smith, S. R. 1968. "Suppression of Radioiodine Releases from a Radiochemical Separations Plant." Nuclear Applications. 5:20-23.

Tachikawa, E., et al. 1971. "Formation of Organic Iodides on Dissolution of Irradiated Uranium Metal in Nitric Acid," International Journal of Applied Radiation and Isotopes. 22: 793-798. 


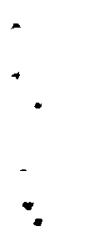

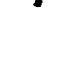




\section{DISTR IBUTION}

No. of

Copies

UNITED STATES

A. A. Churm

DOE Chicago Patent Division

9800 South Cass Avenue

Argonne, IL 60439

R. E. Cunn ingham

Deputy Director for Fuels and Materials

Nuclear Regulatory Commission

Silver Springs, MD 20910

T. C. Chee

DOE Office of Nuclear Waste

Management

Washington, DC 20545

C. R. Cooley

DOE Office of Nuclear Waste

Management

Washington, DC 20545

Sheldon Meyers

DOE Off ice of Nuclear Waste

Management

Washington, DC 20545

R. G. Romatowski

DOE Office of Nuclear Waste Management

Washington, DC 20545

D. M. Rohrer

United States Nuclear Regulatory

Commission

Washington, DC 20555

C. A. Heath

DOE Office of Nuclear Waste

Management

Washington, DC 20545
No. of

Copies

G. Oertel

DOE Office of Nuclear Waste

Management

Washington, DC 20545

A. F. Perge

DOE Office of Nuclear Waste Management

Washington, DC 20545

R. D. Walton

DOE Office of Nuclear Waste Management

Washington, DC 20545

W. E. Mott

DOE Division of Environmental Control Technology

Washington, DC 20545

J. Neff, Program Manager

Department of Energy

Columbus Program Office

505 King Avenue

Columbus, $\mathrm{OH} 43201$

John Van Cleve

DOE Oak Ridge Operations Office

P.0. Box $X$

Oak Ridge, TN 37830

J. B. Whitsett

DOE Idaho Operations Office

550 2nd Street

Idaho Falls, ID 83401

E. S. Goldberg

DOE Savannah River Operations Office

P.0. Box A

Aiken, SC 29801 
No. of

Copies

27 DOE Technical Information Center

J. R. Berreth

Allied Chemical Corporation

550 2nd Street

Idaho Falls, ID 83401

Allied Chemical Corporation

(File Copy)

550 2nd Street

Idaho Falls, ID 83401

A. Williams

Allied-General Nuclear Service P.0. Box 847

Barnwe 11, SC 29812

J. L. Jardine

Argonne National Laboratory

9700 South Cass Avenue

Argonne, IL 60439

M. M. Steindler/L. E. Trevorrow

Argonne National Laboratory

9700 South Cass Avenue

Argonne, IL 60439

Wayne Carbiener

Battelle Memorial Institute

505 King Ave.

Columbus, $\mathrm{OH} 43201$

J. Kircher

Office of Nuclear Waste I solation

Battelle Memorial Institute

505 King Ave.

Columbus, $\mathrm{OH} 43201$

Beverly Rawles

Office of Nuclear Waste I solation

Battelle Memorial Institute

505 King Ave.

Columbus, $\mathrm{OH} 43201$
No. of

Copies

J. W. Voss

Office of Nuclear Waste I solation

Battelle Memorial Institute

505 King Ave.

Columbus, $\mathrm{OH} 43201$

Brookhaven National Laboratory

Reference Section

Information Division

Upton, NY 11973

R. G. Barnes

General Electric Company

175 Curtner Avenue (M/C 858)

San Jose, CA 95125

Los Alamos Scientific Laboratory (DOE)

P.O. Box 1663

Los Alamos, NM 87544

J. P. Duckworth

Plant Manager

Nuclear Fuel Services, Inc.

P.0. Box 124

West Valley, NY 14171

Oak Ridge National Laboratory (DOE)

Central Research Library

Document Reference Section

P.0. Box $X$

Oak Ridge, TN 37830

J. 0. Blomeke

Union Carbide Corporation (ORNL)

Chemical Technology Division

P. 0. Box $Y$

Oak Ridge, TN 37830

R. E. Blanco

Union Carbide Corporation (ORNL)

Chemical Technology Division

P.0. Box $Y$

Oak Ridge, TN 37830 
No. of

Copies

D. E. Ferguson

Union Carbide Corporation (ORNL)

Chemical Technology Division

P.0. Box Y

Oak Ridge, TN 37830

\section{ONSITE}

6 DOE Richland Operations Office

P. A. Craig

0. J. Elgert (3)

H. E. Ransom

M. J. Zamorski

21 Rockwel1 Hanford Operations

L. Brown

J. S. Buck ingham

K. L. Engelhardt

C. J. Evoniuk

R. G. Geier

D. G. Harlow

W. M. Harty

J. 0. Henrie

J. 0. Honeyman

M. J. Kupfer

J. D. Moore

W. E. Ogren

D. E. Place

C. J. Raab

C. W. Reddick

G. Reep

W. W. Schulz

M. J. Smith

R. J. Thompson

R. E. Vander Cook

D. D. Wodrich

Exxon Nuclear Company

S. J. Beard

Westinghouse Hanford

Company

A. G. Blasewitz
No of

Copies

61 Pacific Northwest Laboratory

W. J. Bjork lund

W. F. Bonner

L. A. Bray (34)

L. L. Burger (3)

M. S. Hanson

A. J. Haverfield

J. H. Jarrett

D. E. Larson

J. L. McElroy

J. E. Mende 1

R. E. Nightingale

A. M. Platt

D. L. Prezbindowski (2)

W. A. Ross

J. M. Rusin

J. L. Swanson

H. H. Van Tuyl

R. E. Westerman

Technical Information (5)

Publishing Coordination (2) 


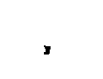

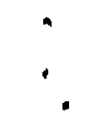

.

$\because$

$=$

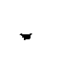
, 